\title{
Factors Affecting Survival in Egyptian Patients Suffering from Urinary Bladder Cancer: A Multicenter Retrospective Study
}

Ahmed Aly Nagy, MD, MSc, PhD¹, Hosam Darweish, MD, MSc, PhD², Hend M. Hamdey Rashed Elkalla, MD,MSc PhD ${ }^{3}$, Heba Abdu-allah, $\mathbf{M S c}^{4}$, Lamiaa Moustafa Ahmed, MSc ${ }^{5}$, Ebtehal Mohamed Salah, MSc ${ }^{6}$, Rasha Haggag, MD,MSc, PhD $^{7}$

${ }^{1}$ Department of Clinical Oncology,Faculty of Medicine, Ain Shams University, Cairo,Egypt, Post.: 21 El Obour Buildings Salah Salem St. Cairo Egypt, P.O. box:11371 ${ }^{2}$ Department of Medical Oncology, Dameitta Oncology Center, Dameitta, Egypt

${ }^{3}$ Department of Clinical Oncology, Faculty of Medicine, Mansoura University, Mansoura, Egypt

${ }^{4}$ Department of Medical Oncology, Dameitta Oncology Center, Dameitta, Egypt

${ }^{5}$ Department of Clinical Oncology, Faculty of Medicine, Ain Shams University, Cairo, Egypt

${ }^{6}$ Department of Clinical Oncology, Faculty of Medicine, Ain Shams University, Cairo, Egypt

${ }^{7}$ Department of Medical Oncology, Faculty of Medicine, Zagazig University, Zagazig, Egypt

\begin{abstract}
Background: Bladder cancer is the second most common malignancy among Egyptian males.

Patients and methods: To investigate the factors affecting survival in Egyptian patients suffering from urinary bladder cancer, we analyzed the geographical patterns of 564 bladder cancers patients from Oncology Departments of Ain Shams University, Mansoura University, Zagazig University and Damietta oncology centerover a period of 7 years between January 2006 and September 2013.

Results: Among the included 564 patients, Males represented $72.5 \%$ of the patients. While, $27.5 \%$ were female with a male to female ratio of 2.6, 227 patients presented with non-metastatic and 337 patients with metastatic urinary bladder cancer. Grade III was found in $36 \%$ of our patients and $60 \%$ of them had stage IV. Mean DFS was $(9.15 \pm 0.5)$ and $(4.4 \pm 0.1)$ while, mean OS was $(13.5 \pm 0.7)$ and $(7.5 \pm 0.15)$ months for non-metastatic, and metastatic patients, respectively. In univariate analysis, patients with no bilharzial infection, Non-SCC, responding patients had significant better DFS and OS vs. patients with bilharzial infection, SCC, non-responding patients (respectively, $p=0.001$ for all). In multivariate analysis, response (OS and PFS), SCC (OS and PFS) and bilharzias is (OS and PFS) where found to be highly statistically significant (Cox regression, $\mathrm{P}<0.001$ for all) in the metastatic and non-metastatic group of patients.
\end{abstract}

Conclusion: Non-responding, SCC type and bilharzial infected patients had significant independent poor prognostic factors for OS and PFS in the metastatic and non-metastatic group of patients.

Keywords: Bladder cancer; Prognostic factors; Survival; Egypt

\section{Introduction}

Worldwide, bladder cancer is considered the ninth most common cancer with a higher incidence in the western world [1] with transitional cell carcinoma (TCC) as the most common histology [2]. The risk factors for development of TCC of the urinary bladder include smoking and occupational toxin exposure [2-8]. Previously published studies have reported a 2.6-fold risk of developing bladder cancer in smokers compared to nonsmokers with adjustment for age, education and marital status [9]. Other studies report a 5.5 increase in bladder cancer risk comparing male regular-smokers to never-smokers after adjusting for high risk occupations [10]. Unlike TCC, the main risk factors for SCC are not environmental exposures, but exposure to infectious agents $[7,11]$. The main cause of SCC in developing countries is Schistosoma haematobium [12,13]. Bladder cancer is one of the most prevalent malignancy among Egyptian males (16\%), accounting for $>7900$ deaths per year, which is considerably higher than most other parts of the world [14]. Countries geographically close to Egypt have lower recorded rates of bladder cancer [15].

Bladder cancer has the second-high prevalence in Egypt It accounts for $12.7 \%$ of male cancers with the majority of cases presented with invasive cancer [16]. In our study, we tried to investigate the factors affecting survival in Egyptian patients suffering from urinary bladder cancer.

\section{Patients and methods}

This is a descriptive, retrospective study of histologically confirmed cases of urinary bladder cancer, seen at Oncology departments of Ain
Shams University, Mansoura University, and Zagazig University and Damietta oncology center over a period of 7 years between January 2006 and September 2013. Data was retrieved from the records of departments. Patients' files kept in the Medical Records and Surgical department were also used for clinical and demographic information. Patients with incomplete data (complete clinical history, age, failure to retrieve histology slides) were excluded from the study. Data were entered and analyzed using SPSS computer software version 15 and STATA 11. Student t-test and Chi square tests were used to establish associations, and significant association was considered when $p$ value was less than 0.05 .

\section{Results}

This study included urinary bladder cancer patients presented to

*Corresponding authors: Rasha Haggag, Faculty of Medicine, Department of Medical Oncology, Zagazig University, Sharkia, Egypt, Tel: 201151600020; E-mail: dr_rmmh@yahoo.com

Received January 25, 2018; Accepted February 13, 2018; Published February 15,2018

Citation: Nagy AA, Darweish $\mathrm{H}$, Hamdey HM, Elkalla $\mathrm{R}$, Abdu-allah $\mathrm{H}$, et al. (2018) Factors Affecting Survival in Egyptian Patients Suffering from Urinary Bladder Cancer: A Multicenter Retrospective Study. J Cancer Sci Ther 10: 031035. doi:10.4172/1948-5956.1000513

Copyright: $\odot 2018$ Nagy AA, et al. This is an open-access article distributed under the terms of the Creative Commons Attribution License, which permits unrestricted use, distribution, and reproduction in any medium, provided the original author and source are credited. 
Citation: Nagy AA, Darweish H, Hamdey HM, Elkalla R, Abdu-allah H, et al. (2018) Factors Affecting Survival in Egyptian Patients Suffering from Urinary Bladder Cancer: A Multicenter Retrospective Study. J Cancer Sci Ther 10: 031-035. doi:10.4172/1948-5956.1000513

Hospitals of Ain Shams, Mansoura, Zagazig University hospitals and Damietta oncology center during the period from the beginning of 2006 to the end of 2013. Five hundred and sixty-four (564) patients with newly diagnosed 227 patients with non-metastatic and 337 patients with metastatic urinary bladder cancer where included in this study.

\begin{tabular}{|c|c|c|}
\hline Factor & No. & Percent \% \\
\hline \multicolumn{3}{|c|}{ PS (ECOG) } \\
\hline$<2$ & 344 & 61.0 \\
\hline$\geq 2$ & 220 & 39.0 \\
\hline \multicolumn{3}{|c|}{ Age } \\
\hline Median & \multicolumn{2}{|c|}{60 (range:40-80 years) } \\
\hline \multicolumn{3}{|c|}{ Sex } \\
\hline Female & 155 & 27.5 \\
\hline Male & 409 & 72.5 \\
\hline \multicolumn{3}{|c|}{ Occupation } \\
\hline Not Working & 155 & 27.5 \\
\hline Working & 409 & 72.5 \\
\hline \multicolumn{3}{|c|}{ Diabetes Miletus } \\
\hline No & 343 & 60.8 \\
\hline Yes & 221 & 39.2 \\
\hline \multicolumn{3}{|c|}{ Viral Hepatitis } \\
\hline No & 314 & 55.7 \\
\hline Yes & 250 & 44.3 \\
\hline \multicolumn{3}{|c|}{ Bilharziasis } \\
\hline No & 416 & 73.8 \\
\hline Yes & 148 & 26.2 \\
\hline \multicolumn{3}{|c|}{ Smoking } \\
\hline No & 280 & 49.6 \\
\hline Yes & 284 & 50.4 \\
\hline
\end{tabular}

Table 1: Clinicopathological Characteristics of the 564 patients.

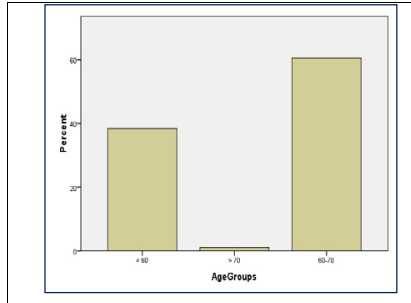

(A): Age distribution

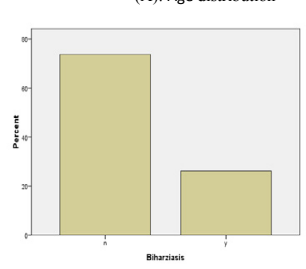

(C): Bilharzial infection distributio

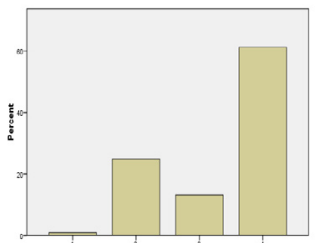

(E): Tumor stage distribution

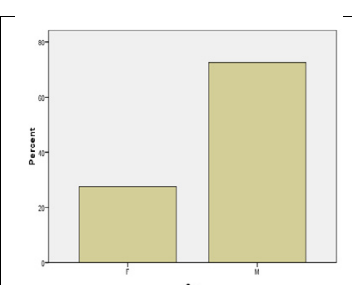

(B): Sex distribution

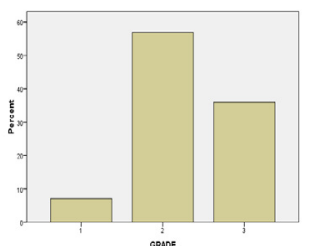

(D): Tumor grade distribution

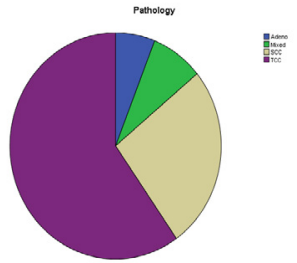

(F): Histo-pathologydistribution
Figure 1: The distribution of the clinico-pathological characteristics between the patients.

\begin{tabular}{|c|c|c|}
\hline Variable & No. & $\%$ \\
\hline \multicolumn{3}{|c|}{ Pathology } \\
\hline Adenocarcinoma & 34 & 6.0 \\
\hline Mixed & 45 & 8.0 \\
\hline Squamous cell carcinoma & 148 & 26.2 \\
\hline $\begin{array}{l}\text { Transitional cell } \\
\text { carcinoma }\end{array}$ & 337 & 59.8 \\
\hline \multicolumn{3}{|c|}{ Grade } \\
\hline I & 40 & 7.1 \\
\hline II & 321 & 56.9 \\
\hline III & 203 & 36.0 \\
\hline \multicolumn{3}{|c|}{ Grading } \\
\hline High Grade (III) & 203 & 36.0 \\
\hline Low Grade (I + II) & 361 & 64.0 \\
\hline \multicolumn{3}{|c|}{ Staging of the non-metastatic patients (227) } \\
\hline I & 5 & 2.2 \\
\hline II & 140 & 61.7 \\
\hline III & 74 & 32.6 \\
\hline IV & 8 & 3.5 \\
\hline
\end{tabular}

Table 2: Tumor characteristics.

Clinico-pathological characteristics of the patients were summarized in Table 1 and Figure 1. For all patients, the median age was 60 years old with a range of (40-80 years), males represented $72.5 \%$ of the patients while; $27.5 \%$ were female with a male to female ratio of 2.6. Regarding smoking history, nearly smokers and non-smokers were equal. ECOG Performance status of $61 \%$ of patients was $<2$ while, $39 \%$ of them were $\geq 2$. Bilharziasis infection was noted in $74 \%$ of patients and only $26 \%$ of them were free. Diabetes mellitus (DM) and viral hepatitis were found in our cases by about $39 \%$ and $55.7 \%$ respectively. The most common pathological types were TCC in about $60 \%$ of patients followed by SCC in $26 \%$ of the patients (Table 2). So, the non-squamous cell carcinoma to squamous cell carcinoma ratio was 2.8 . Fifty-seven percent $(57 \%)$ of tumors were of grade II while grade III found in $36 \%$ of them only. So, high grade tumors in our study cases (36\%) were less in occurrence compared with the low-grade tumors (64\%). Three hundred and thirtyseven (337) patients were presented with stage IV and they form about $60 \%$ of all the patients while the other stages were $40 \%$ of the patients (227). Stage II was forming about $25 \%$ of the whole patients (Table 2 ).

As shown in Table 2, the group of non-metastatic patients (227 patients) showed that $61.7 \%$ of them were diagnosed with stage II bladder cancer while stage III showed $32.6 \%$ approximately. Only 5 cases presented with stage I and the total number of cases presented with positive pelvic nodes and received adjuvant treatment (stage IV) were just 8 cases. In patients who were treated with curative intent (227), Sixty percent of them (135 patients) received the protocol of Gemzar-cisplatin. Cisplatin and 5FU were given in 25.5\% (58 patients). The rest of patients were received Gemzar-carboplatin and MVAC equally by about $7 \%$. Local recurrence occurred in $46 \%$ while distant metastasis in $56 \%$. One hundred sixty-one patients (71\%) were treated for the relapse by taxanes and $27 \%$ of them (61 patient) with BSC. One hundred and forty-three patients (63\%) showed response after the 1st line treatment for the relapse while 84 patients (37\%) showed progressive disease as mentioned in Table 3 . In the metastatic group of patients (337), there was lung metastasis in about $41.5 \%$ of the patients which is the highest percent of recurrence events followed by local pelvic recurrence by about $33 \%$ of the total number of the metastatic patients. Bone metastasis was $13.5 \%$ followed by $11.5 \%$ for the liver metastasis. For those patients with metastasis, the $1^{\text {st }}$ line treatments were gemzar-cisplatin, cisplatin-5FU and gemzar-carbopaltin with the percent of $60 \%, 26 \%$ and $14 \%$ respectively. The patients with stable disease after $1^{\text {st }}$ line treatment was $59.3 \%$; while those with progressive 
Citation: Nagy AA, Darweish H, Hamdey HM, Elkalla R, Abdu-allah H, et al. (2018) Factors Affecting Survival in Egyptian Patients Suffering from Urinary Bladder Cancer: A Multicenter Retrospective Study. J Cancer Sci Ther 10: 031-035. doi:10.4172/1948-5956.1000513

disease were $26.1 \%$. Partial response just occurred in $14.5 \%$. Fifty six percent $\left(189\right.$ cases) of the cases received taxanes as $2^{\text {nd }}$ line treatment. Only $9 \%$ of the cases received salvage palliative radiotherapy. The rest of the patients (117 cases) forming about $34.5 \%$ just had best supportive care (BSC) as shown in Table 4.

\section{Survival data}

For non-metastatic patients, mean DFS was $(9.15 \pm 0.5)$ while, mean OS was $(13.5 \pm 0.7)$. For metastatic patients, mean PFS was $(4.4 \pm 0.1)$ while, mean OS was $(7.5 \pm 0.15)$. In univariate analysis, patients with no bilharzial infection, non-SCC, responding patients had significant better DFS and OS vs. patients with bilharzial infection. SCC, non-responding patients (respectively, $\mathrm{p}=0.001$ for all; (Figures 2 and 3). In multivariate analysis, no response, SCC type and bilharzial

\begin{tabular}{|c|c|c|}
\hline Adjuvant treatment & No. & $\%$ \\
\hline Cisplatin/5FU & 58 & 25.6 \\
\hline Gemcitabine/Carb & 16 & 7.0 \\
\hline Gemcitabine/cisplatin & 135 & 59.5 \\
\hline MVAC & 18 & 7.9 \\
\hline Site of Relapse & No. & $\%$ \\
\hline Local and Regional (L) & 105 & 46.3 \\
\hline Distant(M) & 122 & 53.7 \\
\hline Treatment after Relapse & No. & $\%$ \\
\hline Supportive (BSC) & 61 & 26.9 \\
\hline Gemcitabine & 5 & 2.2 \\
\hline Taxanes & 161 & 70.9 \\
\hline Response after relapse & No. & $\%$ \\
\hline Non-Responding (PD) & 84 & 37.0 \\
\hline Responding & 143 & 63.0 \\
\hline
\end{tabular}

Table 3: Treatment and outcome

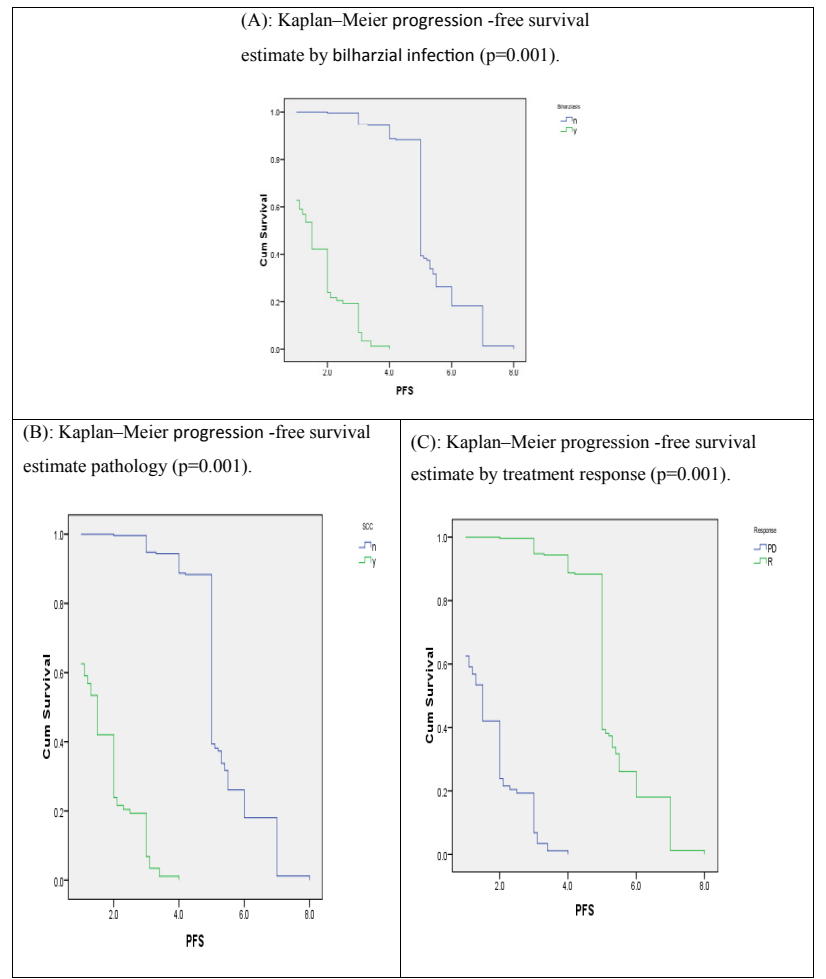

Figure 2: Kaplan-Meier progression-free survival estimate by bilharzial infection, pathology and treatment response.

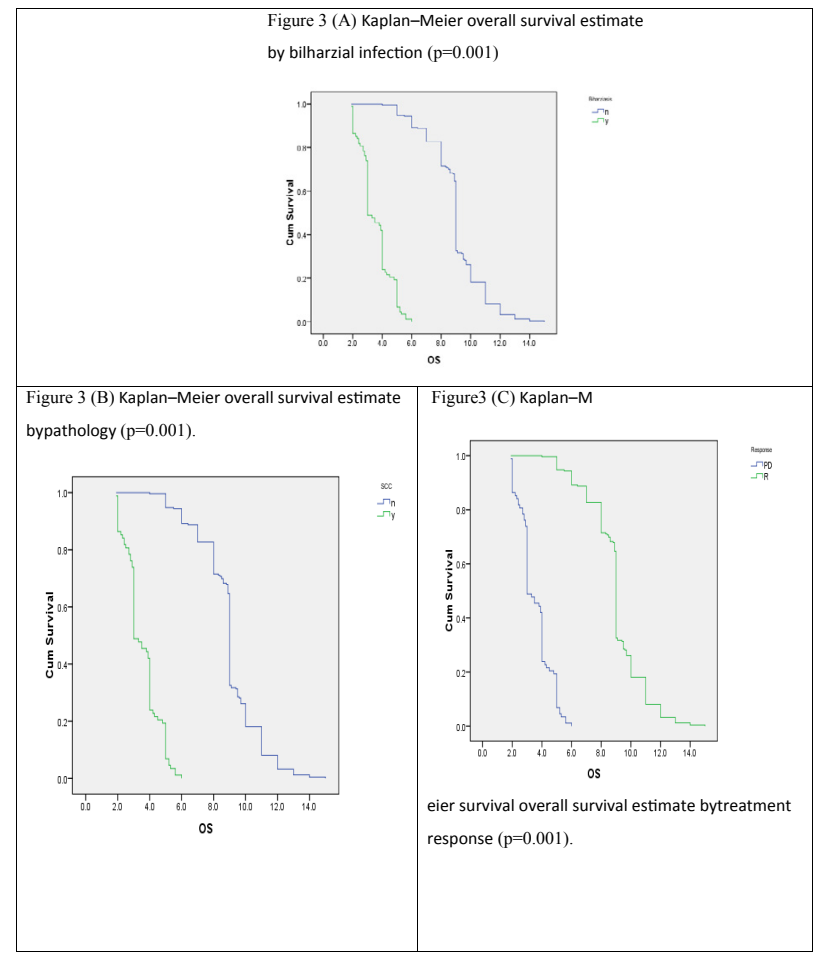

Figure 3: Kaplan-Meier overall survival estimate by bilharzial infection, pathology and treatment response.

\begin{tabular}{|c|c|c|}
\hline Variable & No. & $\%$ \\
\hline Bone (B) & 46 & 13.6 \\
\hline Liver & 39 & 11.6 \\
\hline Lung of metastasis & 41.5 \\
\hline \multicolumn{2}{|c|}{ First line treatment } \\
\hline Cisplatin /5FU & 140 & 26.1 \\
\hline Gemcitabine/carboplatin & 47 & 13.9 \\
\hline Gemcitabine /cisplatin & 202 & 59.9 \\
\hline Response after first line treatment & 26.1 \\
\hline Progression (PD) & 88 & 14.5 \\
\hline Partial Response (PR) & 49 & 59.3 \\
\hline Stable Disease (SD) & 200 & 34.7 \\
\hline Supportive Care (BSC) & 117 & 9.2 \\
\hline Radiation (RTH) & 31 & 56.1 \\
\hline Taxanes & 189 & \\
\hline
\end{tabular}

Table 4: Metastatic cases sites, treatment and response.

infection where found to be significant independent poor prognostic factors for OS and PFS in the metastatic and non-metastatic group of patients $(\mathrm{P}<0.001$ for all; (Tables 5 and 6).

\section{Discussion}

In Egypt, bladder cancer has been the most common cancer during the past 50 years. A significant decline in the relative frequency of bladder cancer (from $27.6 \%$ to $11.7 \%$ ) was observed in the past 37 years by analysis of 9843 patients at the department of pathology, NCI, Cairo University [17]. A series of 564 bladder cancer data were analyzed for clinico-pathological characteristics, systemic management and outcome as well as the prognostic factors that affect the survival, the results were compared with findings reported from other studies. 
Citation: Nagy AA, Darweish H, Hamdey HM, Elkalla R, Abdu-allah H, et al. (2018) Factors Affecting Survival in Egyptian Patients Suffering from Urinary Bladder Cancer: A Multicenter Retrospective Study. J Cancer Sci Ther 10: 031-035. doi:10.4172/1948-5956.1000513

\begin{tabular}{|c|c|c|c|c|}
\hline \multirow{2}{*}{ Variables } & \multicolumn{2}{|c|}{ DFS } & \multicolumn{2}{c|}{ OS } \\
\cline { 2 - 5 } & Hazard ratio (HR) & P-value & Hazard ratio (HR) & P-value \\
\hline Age & 1.109 & 0.489 & 1.118 & 0.456 \\
\hline PS & 1.087 & 0.576 & 1.133 & 0.406 \\
\hline Sex & 0.877 & 0.499 & 0.733 & 0.106 \\
\hline Diabetes & 1.560 & 0.055 & 1.134 & 0.573 \\
\hline Hepatitis & 0.660 & 0.074 & .724 & 0.147 \\
\hline Biharziasis & 0.107 & $<0.001$ & 0.017 & $<0.001$ \\
\hline Smoking & 1.270 & 0.178 & 1.347 & 0.092 \\
\hline $\begin{array}{c}\text { Squamous } \\
\text { cell } \\
\text { carcinoma }\end{array}$ & 0.100 & $<0.001$ & 0.015 & $<0.001$ \\
\hline $\begin{array}{c}\text { Grading } \\
\text { Response }\end{array}$ & 1.543 & 0.087 & 1.577 & 0.089 \\
\hline
\end{tabular}

that treatment end-results were not affected by tumor histology or etiology but affected by other prognostic factors like stage, grade, nodal involvement [26-29].

\section{Conclusion}

The epidemiology of bladder cancer was dramatically shifted in Egypt with a lower incidence of SCC, a greater incidence of TCC, older age at diagnosis, and a decrease in the male/female ratio. Non-SCC, responding patients and non bilharzial BC had significant better DFS and OS. More prospective using these poor prognostic markers may be for risk stratification and predictive for other alternative therapies is recommended.

\section{References}

Table 5: Multivariate analyses by Cox regression model for non-metastatic patients.

\begin{tabular}{|c|c|c|c|c|}
\hline \multirow{2}{*}{ Variables } & \multicolumn{2}{|c|}{ PFS } & \multicolumn{2}{c|}{ OS } \\
\cline { 2 - 5 } & Hazard ratio (HR) & P-value & Hazard ratio (HR) & P-value \\
\hline Age & 1.068 & 0.579 & 1.086 & 0.4 \\
\hline PS & 1.021 & 0.859 & 1.012 & 0.9 \\
\hline Sex & 1.133 & 0.318 & 1.205 & 0.4 \\
\hline Diabetes & 1.100 & 0.671 & 0.971 & 0.89 \\
\hline Hepatitis & 0.876 & 0.549 & 0.971 & 0.7 \\
\hline Biharziasis & 0.027 & $<0.001$ & 0.024 & $<0.001$ \\
\hline $\begin{array}{c}\text { Squamous } \\
\text { cell }\end{array}$ & 0.027 & $<0.001$ & 0.024 & $<0.001$ \\
\hline carcinoma & 0.19 & 1.299 & 1.186 & 0.4 \\
\hline Grading & 37.678 & $<0.001$ & 41.955 & $<0.001$ \\
\hline Response & & & & \\
\hline
\end{tabular}

1. Parkin DM, Bray F, Ferlay J, Pisani P (2002) Global cancer statistics. CA Cancer J Clin 55: 108.

2. Golka K, Wiese A, Assennato G, Bolt HM (2004) Occupational exposure and urological cancer. World J Urol 21: 391.

3. Morales K, Ryan L, Kuo T, Wu M, Chen C (2000) Risk of internal cancers from arsenic in drinking water. Environ Health Perspect 108: 662.

4. Smith A, Goycolea M, Haque R, Biggs M (1998) Marked increase in bladder and lung cancer mortality in a region of northern Chile due to arsenic in drinking water. Am J Epidemiol 147: 660-669.

5. Chen GJ, Chuang YC, You SL, Lin TM, Wu HY (1986) A retrospective study on malignant neoplasms of bladder, lung, and liver in Blackfoot disease endemic area in Taiwan. Br J Cancer 53: 405.

6. Office of the Surgeon General (US); Office on Smoking and Health (US) (2004) The Health Consequences of Smoking: A Report of the Surgeon General Atlanta (GA): Centers for Disease Control and Prevention (US)

Table 6: Multivariate analyses by Cox regression model for metastatic patients.

This study found that the median age at diagnosis for urinary bladder cancer, was 60 (range: 40-80 years) which is in agreement with previous Egyptian studies [18-20]. In the present study, bilharzial infection was in $73 \%$ of the patients, comparable to that was reported by El- Bolkainy [21] and Gouda et al. [17]. Which were $82 \%$ and $55.3 \%$ respectively [14].

In our study, 337 patients (59.8\%) had TCC and 148 patients (26.2\%) had SCC. This is comparable to that was found by Band et al. [22], who demonstrated significant changes in the histo-pathological types of bladder cancer in Egypt over the past 26 years; the relative frequency of TCC in this multi-year sample increased from $22 \%$ in 1980 to $73 \%$ of bladder diagnoses in 2005 , while SCC decreased from $78 \%$ to $27 \%$ of diagnosed bladder tumors. Decline in SCC may be explained by reductions in schistosomal infection, increases in cigarette smoking and chemical exposures related to occupational hazards. Males represented $72.5 \%$ of the patients. While, $27.5 \%$ were female with a male to female ratio of 2.6 in our study, approximately three times as many males as females, a pattern similar to that found in previous Egyptian studies [14] and in other countries [22]. We found that the incidence is nearly equal between smokers and nonsmokers, the same reported by Salem et al. [23]. Of the non-metastatic patients, stage II, III were represented in (140/227) $61.7 \%$ and (74/227) $32.6 \%$ while incidence of noninvasive bladder cancer (stage I) were found in (5/227) $2.2 \%$ of the patients, this correlates with findings of Mohktar et al. 2007 [24] and Amin et al. [25]. In multivariate analysis of our study, no response, SCC type and bilharzial infection were found to be significant independent poor prognostic factors for OS and PFS in the metastatic and non-metastatic group of patients. While, in Schistosoma-associated bladder cancer, Ghoneim et al. [26], the multivariate analysis proved that tumor cell type is not an independent working factor determining the OS. In concordance with our results, many authors cautiously concluded

7. Murta NC, Schnitz DB, Zeegers M, Steineck G, Kogevinas M, et al. (2007) Epidemiology of urinary bladder cancer: from tumor development to patient's death. World J Urol 25: 285-295.

8. Pitard A, Brennan AP, Clavel J, Greiser E, Lopez AG, et al. (2001) Cigar, pipe and cigarette smoking and bladder cancer risk in European men. Cancer Causes Control 12: 551-556.

9. Alberg AJ, Kouzis A, Genkinger JM, Gallicchio L, Burke AE, et al. (2007) A prospective cohort study of bladder cancer risk in relation to active cigarette smoking and household exposure to secondhand cigarette smoke. Am J Epidemiol 165: 660-666.

10. Samanic C, Kogevinas M, Dosemeci M, Malats N, Real F, et al. (2006) Smoking and bladder cancer in Spain: effects of tobacco type, timing, environmental tobacco smoke, and gender. Cancer Epidemiol Biomarkers Prev 15: 1348-1354.

11. Shokeir A (2004) Squamous cell carcinoma of the bladder: pathology, diagnosis and treatment. BJU Int. 93: 216-220.

12. Mostafa M, Sheweita S, O'Connor P (1999) Relationship between schistosomiasis and bladder cancer. Clin Microbiol Rev 12: 97-11.

13. International Agency for Research on Cancer (1994) IARC monographs on the evaluation of the carcinogenic risk to humans. Volume 61 , Schistosomes, liver flukes, and Helicobacter pylori. IARC

14. Khaled $\mathrm{H}$ (2005) Systematic management of bladder cancer in Egypt: revisited J Egypt Natl Canc Inst 17: 127-131.

15. Freedman LS, Edwards BK, RiesLAG, Young IL (2006) Cancer Incidence in Four Member Countries (Cyprus, Egypt, Israel, and Jordan) of the Middle East Cancer Consortium (MECC) Compared with US SEER

16. Ibrahim AS, Khaled HM, Mikhail NH, Baraka H, and Kamel H (2014) Cancer Incidence in Egypt: Results of the National Population-Based Cancer Registry Program. J Canc Epidemiol 1-17.

17. Gouda I, Mokhtar N, Bilal D, El-Bolkainy T, El-Bolkainy NM (2007) Bilharziasis and bladder cancer: A Time trend analysis of 9843 Patients. J Egypt Natl Canc Inst 19: 158-162.

18. Khaled HM, Aly MS, Magrath IT (2000) Loss of $Y$ chromosome in bilharzial bladder cancer. Cancer Genet Cytogenet 117: 32-36. 
Citation: Nagy AA, Darweish H, Hamdey HM, Elkalla R, Abdu-allah H, et al. (2018) Factors Affecting Survival in Egyptian Patients Suffering from Urinary Bladder Cancer: A Multicenter Retrospective Study. J Cancer Sci Ther 10: 031-035. doi:10.4172/1948-5956.1000513

19. Khaled H, Emara ME, Gaafar RM, Mansour O, Abdel Warith A, et al. (2008) Primary chemotherapy with low-dose prolonged infusion gemcitabine and cisplatin in patients with bladder cancer: A Phase II trial. Urol Oncol 26: 133136.

20. Haggag R, Farag K, Abu-Taleb F, Shamaa S, Zekri AR, et al. (2014) Lowdose versus standard-dose gemcitabine infusion and cisplatin for patients with advanced bladder cancer: a randomized phase II trial-an update. Med Oncol 31: 811.

21. El BMN, Mokhtar NM, Ghoneim MA, Hussein MH (1981) The impact of schistosomiasis on the pathology of bladder carcinoma. Cancer 48: 2643-2648.

22. Band P, Le N, MacArthur A, Fang R, Gallagher R (2005) Identification of occupational cancer risks in British Columbia: A population-based case-contro study of 1129 cases of bladder cancer. J Occup Environ Med 47: 854-858.

23. Salem HK, Mahfouz S (2012) Changing patterns (age, incidence, and pathologic types) of schistosoma-associated bladder cancer in Egypt in the past decade. Urology 79: 379-383.
24. Mohktar N, Gouda I, Adel I (2007) Malignant urinary system tumors Cancer pathology registry.

25. Amin AF (2013) Epidemiological study of bladder cancer and risk factors in Upper Egypt. AAMJ 11: 305-316.

26. Ghoneim MA, Abdel-Latif M, El-Mekresh M, Abol-Enein H, Mosbah A, et al. (2010) Radical cystectomy for carcinoma of the bladder: 2,720 consecutivecases 5 year later. J Urol 180: 121-127.

27. Zaghloul MS (2010) Adjuvant and neoadjuvant radiotherapy forbladder cancer: revisited. Future Oncol 6: 1177-1191.

28. Scosyrev E, Yao J, Messing E (2009) Urothelial carcinoma versus squamous cell carcinoma of bladder: is survival different with stage adjustment? Urology $73822-73827$.

29. Ploeg M, Aben KK, Hulsbergen CA, Schoenberg MP, Witjes JA, et al. (2010) Clinical epidemiology of nonurothelial bladder cancer: analysis of The Netherlands Cancer Registry. J Urol 183: 915-920. 